\title{
Understanding Islamic Spiritual Leadership Applied In Business: A Case Study At Baitul Mal Wat Tamwil Usaha Gabungan Terpadu Sidogiri Indonesia
}

\author{
Helmi Muhammad, Moeljadi, Nur Khusniyah Indrawati, Atim Djazuli
}

\begin{abstract}
This study aimed to investigate the values of Islamic spiritual leadership applied at Baitul Mal wat Tamwil (BMT) Usaha Gabungan Terpadu (UGT) Sidogiri Indonesia and how it motivated and inspired the employees through the establishment of vision and culture based on Islamic values that affect their working productivity and commitment. This study was based on a post-positivist paradigm, and it was a single case study. Indepth interviews were applied for a data collection which was obtained from several research informants. These interviews were recorded, then transcribed to be analyzed using an interactive model. The results showed that spiritual leadership at BMT UGT Sidogiri Indonesia was based on three bases; they are Iman (faith to Allah), Islam and Ihsan (ethic). The value of Iman was reflected through the working seriously, discipline, always supervised, accompanied, and protected by Allah. Next, the value of Islam was reflected through the commitment of doing congregational prayers (salat al-jamaah). An Individual who has an outstanding religious commitment will not forget religious ethics such as being discipline, honest, virtuous, not arbitrary to others and responsible for the job. Furthermore, the value of Ihsan was reflected through working culture. This culture was taken from the personality characters of Prophet such as shiddiq (honest), amanah (trustworthy), tabligh (deliver), and fathonah (intelligent).
\end{abstract}

Index Terms: Spiritual Leadership, Shiddiq, Amanah, Tabligh, Fathonah.

\section{INTRODUCTION}

Studies on spiritual leadership have become the attention of many experts $[1,2]$, and widespread interest to be studied in many fields [3], such as in education [4], public administration [5], and military academy [6]. In fact, a spiritual leadership nowadays emerges as new theory and model in the leadership practice in global organization, public and private organization in which the employees come from different cultural backgrounds, beliefs, and religions [7]. Regarding this issue, various previous research asserts that spiritual leadership has been newly implemented in the religious [8], medical [9,10], workplace [11] and even entrepreneurship or business aspects [8]. Spiritual

Revised Manuscript Received on April 19, 2019. Brawijaya, Malang, Indonesia. Faculty of Islamic Studies, Universitas Islam Raden Rahmat, Malang, Indonesia.

Moeljadi, Faculty of Economics and Business, University of Brawijaya, Malang, Indonesia.

Nur Khusniyah Indrawati, Faculty of Economics and Business, University of Brawijaya, Malang, Indonesia.

Atim Djazuli, Faculty of Economics and Business, University of Brawijaya, Malang, Indonesia.
Helmi Muhammad, Faculty of Economics and Business, University of

leadership becomes vital since the spiritual values supporting many organizational activities [12].

Many studies revealed positive effects of spiritual values in business. Spiritual business is significant in increasing business creativity [12], improving employees' commitment and interpersonal relationship [13], as a foundation or motivational drive for ethics [14], increasing employees' performance [15] and bringing positive impacts to the spiritual health in their old age [16]. The application of spiritual values in business will make businessman becomes a successful leader [17] and will be considered as an essential foundation in effective leadership [9] and today's practices of organizational management [18].

The implementation of spiritual leadership values in business makes business more ethical than just looking for the financial aspect [19]. Further, postmodernism business and modern era construction experience disappointment as an effect of worldly love then toward spirituality [20]. The managerial leadership of the multinational company has also created many ethical problems in business practice [21]. Recent studies show the bribery scandal and the arrogance of modern business executives which are far from ethical value, such as the scandal of Mabey and Johnson construction company in England [22]. Hence, it becomes a lesson about leadership failure, which is far from spirituality values. Thus, making business becomes ethical and successful will require spiritual values which are implemented in the leadership [14,17].

The studies on spiritual leadership all this time are broadly conducted to multinational companies [23-26] and still scarcely conducted in small companies [27], as well as it has never been conducted in the business context such as Islamic Boarding School-based sharia microfinance institution. Whereas, the Islamic boarding school has a significantly high potential not only in the field of education but also in economic development [28-30]. The latest data from Directorate General of Islamic Education Ministry of Religion Republic of Indonesia, it is known that the number of Islamic boarding schools in Indonesia is 28.984. Based on the number of the Islamic boarding school, one of the boarding schools which emphasizes on the alumni to be aware of the society's economic development is Sidogiri boarding school through sharia microfinance institution 
Baitul Mal wat Tamwil (BMT) Usaha Gabungan Terpadu (UGT) Sidogiri Indonesia. Interestingly, even though it is managed by the alumni of the Islamic boarding school who commonly do not have a bachelor's degree. BMT UGT Sidogiri Indonesia currently has 18.060 members with a total asset of more than 2.4 trillion until it occupies the most significant cooperation in Indonesia.

The phenomenon of BMT UGT Sidogiri Indonesia with the achievements and business management based on Islamic boarding school is interesting to be explored regarding its business aspect ethically through spiritual leadership. Besides, it enables different perspective in the implementation of spiritual leadership actualized in the business. Through this study, the success of BMT UGT Sidogiri Indonesia in implementing the business practice ethically though spiritual leadership contributes to positive impacts on business development.

\section{LITERATURE REVIEW}

The basic concept of spiritual leadership derives from the word spirit. In general, the word spirit originated from Latin words spiritus, which means breath. Furthermore, Fairholm states that spirit means an abstract power that makes people survive [5]. In this case, it can be defined as a soul [34], which means something that can give life, and it is significantly vital for human beings.

Spiritual leadership concept propounds a new paradigm in the adaptive transformation and development of the organization to answer the challenge of time in the $21 \mathrm{st}$ century. This spiritual leadership is perceived to be able to improve previous leadership models by grounding their leadership mission, vision, and behavior on divine values [35]. Spiritual leadership is a construction that reveals in the broader workplace regarding the spiritual context needed by organization member, transcendent, and intrinsically motivating ourselves and others [6].

Furthermore, Fry defines spiritual leadership as values, attitudes, and behaviors that motivate oneself and others [36]. In this case, it is necessary to have a similar vision and organizational culture from all members based on altruistic love from the leaders and subordinates in case they have a genuine concern for themselves and others. Furthermore, Fry also explains that spiritual leader is someone who can be a role model, a motivator, and friends to others. Meanwhile, Smith \& Rayment define spiritual leadership as a view of the leaders based on their experiences to understand the feelings to support and build relationships with others [37]. On the other hand, spiritual leadership is a holistic leadership theory that integrates four basic human elements, and they are the body (physical), mind (ratio), heart (emotion, feeling), and spirit $[6,36]$.

Spiritual leadership is a leadership that brings worldly dimensions to the spiritual one and God as the true leader that inspires, influences, and moves the human conscience through religious and ethical approaches [38]. In this case, the characteristics of spiritual leadership based on religious ethics include the honesty of the heart, fairness, selfknowledge, focus on pious charity, non-dogmatic spiritualism, work more efficiently, awaken the best in oneself and others, openness, acceptance, discipline but remain flexible, relaxed, and intelligent, as well as modest $[35,38]$.

In the Islamic view, the model of spiritual leadership refers to the pattern of the leadership of Prophet Muhammad SAW with the most ideal leadership qualities, they are Shiddiq (integrity), Amanah (trust), Tabligh (openly, human relations), and Fathonah (working smart) [39]. In other words, spiritual leadership leads by heart based on religious ethics, which can shape characters, integrity, and exemplary. This leadership model is not influenced by external factors alone, but it is more guided by internal factors of conscience. However, spiritual leadership does not mean an anti-intellectual leadership; it is exceptionally rational and clarifies the rationality with the guidance of conscience and spiritual intelligence [38].

\section{METHODOLOGY}

This qualitative study employed a post-positivist paradigm [40] using the single-case study as the research focus as stated by Yin [41] concerning spiritual leadership occurred in BMT UGT Sidogiri Indonesia by considering its uniqueness and characteristics implemented within 2018. The key informants were selected purposively, such as the heads of managers since they know better, expert and directly involved in the research problems, and other informants were selected using a snowballing technique namely the Chief Director, supervisors, and heads of branches. The data collection was conducted through an indepth interview with the informants. The interview results were then recorded and transcribed for a discussion topic. The data analysis technique used in this study was an interactive model [42]. The quality standard of research data was conducted through triangulation.

\section{RESULTS AND FINDINGS}

Spiritual leadership is a leadership based on religious ethics, God as a reference that impacts on the ethics, behavior, leadership patterns, and actions [38]. In history, Prophet Muhammad SAW was the best model for spiritual leadership. He was inspired by the nature of God's leadership and then applied them to lead men. Based on the results of field studies, there have been found some of the main bases in the spiritual leadership, they are Iman, Islam, and Ihsan, which then generate or produce noble values applied in BMT UGT Sidogiri. Here is the explanation:

\section{A. Iman (faith to Allah) Bases}

Faith to Allah SWT is the basic foundation of various activities in shaping certain attitudes and practices that aim to worship [43]. Iman (faith to Allah) is also the primary basis that impacts to life, soul, body, attitudes, and behavior thoroughly. Furthermore, faith or belief in Allah is not only understood in the context of rituals but also implements into virtue charities [44].

The results of the investigation showed that the use of Islamic spirituality, based on the belief of Allah SWT, produces a high spirit in business acts. The implementation 
of Islamic fiqh or Islamic sharia in every business matter can be noticed in a soul based on strong faith to Allah. As stated by the Chairman of the Board of BMT UGT Sidogiri, that:

"Fiqh is about the knowledge of Islamic law, which can be read by anybody. Fiqh prayer, for example, it is about the rule of prayer, not about how to do actual prayer. Aqimissholatalidzikri, it is not fiqh. Man tafaqqoha, walamyatashowwaf, faqodtafassaqo. Wamantashowwafa, wa lam yatafaqqoh, faqodtazandaqo. Hence, fiqh is not the tasawuf (mysticism). However, there are experts studying prayer (salat); they understand zakat, but never implement it. Thus, how can you get the spirit? So, it is not a promise that someone who learns fiqh will have a good faith ".

Thus, a manifestation of faith in spiritual leadership is implemented through the belief that Allah SWT becomes an inspiration through His good qualities to apply in every action. Moreover, it is convinced that every effort is a part of worship which is completed as well as useful for others [35]. Furthermore, The aspects that can be derived from faith in this spiritual leadership are (a) trusting Allah SWT and all aspects of the pillars of faith, (b) using good qualities of God(Allah) as the reference, (c) work hard and followed by surrender (tawakal) to Allah SWT, (d) applying the values of the faith in business activities such as the focus during the work, discipline, feeling constantly watched, accompanied, guarded, seen by Allah, and $\mathrm{He}$ is always beside him [45].

The findings showed that the implementation of sharia should be based on faith or Iman to Allah SWT. Financial Supervisor of BMT UGT Sidogiri also shared the same view. He stated:

"... so how can non-Muslims be able to live, if those just do not believe (not faith) to make the provisions of Islamic Sharia".

Faith in God by using His good qualities and implement them in business activities will bring significant benefits. These benefits in Islamic concepts must refer to the two phases of human life; they are the world of life and the afterlife $[46,47]$. This concept is undoubtedly different from conventional business ethics that significantly emphasizes the material benefit from a worldly goal [44].

Faith is the basic foundation which becomes the reinforcing factor in the decision to do business by following sharia law determined by orientation, seeking for halal wealth and leaving the haram. Although many business people have many choices, strong faith becomes the framework of work, which leads to the right business [48]. Therefore, the business based on faith and performed based on the right regulations is a part of worship to Allah, since the business is run by obedience to Islamic sharia law [49]. As stated by Director of Finance and Human Resource:

“...In UGT Sidogiri, maintaining trust and good moral are involved as stewardship of employee's mental. Besides, excellent service in a financial institution is a kind of effort to emulate Prophet. Hence, the will for excellent service should be based on Prophet, not the company or institution to gain the reward of goodness".

\section{B. Islamic (Sharia) Bases}

The implementation of Islam through the sharia is intended to give positive values that become the spirit of every action and business activity. In this case, the implementation of Islamic law based on belief (tawheed to Allah SWT) will strengthen the spirituality of business players regarding the harmonious relationship of world destiny, and hereafter can be implemented. Furthermore, a person who is committed to his/her religion, through the implementation of sharia, will not forget the ethics of work such as discipline, honesty, good manners, not arbitrary to others, and responsible for the task given.

The findings of investigation showed that the implementation of Islamic sharia in BMT UGT Sidogiri starts from the congregational prayers which are conducted on time and it has a significant impact on the values of discipline, both time discipline, and discipline of organizational rules, as the Chairman of the Board of BMT UGT Sidogiri said that:

"... at 7 am, duha prayer, continued to early zuhr and as prayers which are called a discipline in doing a prayer. Hence, fostering a disciplined mentality will require discipline prayers and time. Therefore, a good discipline prayer will guide us to avoid evil things".

Performing salat is a part of sharia adherence, which leads the person to have good self-discipline that rises due to selfawareness and consciousness as well as controllers of individual deviant acts. Furthermore, strengthening the discipline is based on awareness, consciousness, responsible, give priority to others. Moreover, fostering selfdiscipline will influence the group discipline, which means that groups can produce an excellent work performance if each member contributes their work based on their right and responsibility. Self and group disciplines compete and support each other.

The implications of disciplined prayer are on the discipline of working time and the established rules. Furthermore, this attitude is run with sincere intention and willingness to alter by following the policies made by the government. This attitude is characterized by various initiatives, willingness to obey the time and regulations of the organization. Obedience to these times and rules as conveyed by the Chairman of the Board of BMT UGT Sidogiri that:

"The point needed in the business is the discipline of time and rules. At BMT UGT Sidogiri, if the meeting is at 9 o'clock, it is run at 9 o'clock. For example, Last Saturday, there was a meeting of the Indonesian leaders, at 10 o'clock. We began at 10 o'clock. There were late participants, only a few, sometimes they get stuck in the traffic jam, and so on, but they already had a passion for discipline ".

The precision of commitment on tasks and work holistically, both on time, quality of work, work system is highly potential for the sustainability of BMT UGT Sidogiri. The implementation is the discipline in working hours, the standardization of work, the targets are fulfilled, the manufacture of information technology-based systems, 
excellent service, togetherness, and such.

\section{Ihsan Bases}

The excellent implementation of faith to Allah and Sharia will impact on ethical behavior (ihsan) in a person. Ihsan is carrying out good deeds that give benefits to others without expecting the reward of the deed [50]. Furthermore, ihsan means to do good in the right way. Ihsan aims to improve the quality of humans in their performance. Good quality is not only related to the activities of worldly life but also hereafter $[46,47]$.

The implementation of ihsan in spiritual leadership is presenting good behaviors in the organization to obtain happiness in living in the world and the hereafter [47], in human relations with God, with oneself, with others, and nature [49]. This value of ihsan leads humans not to do damage and implemented in the life of doing business and organization, which become a work culture.

The investigation results showed that ihsan values in BMT UGT Sidogiri emulate the Prophet Muhammad SAW which apply continuously the work culture, namely shiddiq, amanah, tabligh, and fathonah. The Chairman of the Board of BMT UGT Sidogiri stated:

"Our Prophet, Muhammad SAW had the characteristics of shiddiq, tabligh, amanah,and fathonah. The Prophet is an ideal leader in every aspect. The leadership of the Prophet must be imitated. Whoever can imitate the leadership of the Prophet, they can also be ideal. This means that if people can implement the characteristics of shiddiq, tabligh, amanah, and fathonah on every aspect, then they can establish an ideal institution, or their leadership is an ideal one".

The characteristics of Prophet Muhammad SAW are used as a reference of work ethicat BMT UGT Sidogiri, then described one by one in the operational unit and obeyed as a reference work, namely:

\section{a) Shiddiq (honesty)}

Shiddiq is honesty. Honesty becomes the most crucial character in the Islamic business blessed by Allah SWT as well as becomes the contributing factor of blessings. The implementation of shiddiq character is that all leaders starting from the managers until employees must have honesty character in doing their duty. There is conformity between sayings and behavior. Saying is the connector of conscience; therefore, there is unity between tongue and heart. This what differentiates between an individual who committed and a hypocrite. The shiddiq business manager does not have a lousy record of accomplishment in their behavior. What they perform can be accounted for to stakeholders as social worship and to Allah SWT as individual worship.

\section{b) Amanah (trustworthy)}

Amanah means trustworthy. The amanah element becomes a significant aspect in business, which has a positive implication in generating customer satisfaction and trustworthy through excellent accountability on their given amanah. Accordingly, consumer loyalty can be obtained to achieve business sustainability. The implementation of amanah values positively correlated between behavior and sayings, correspondence of financial report and actual transaction, note-taking on income an outcome according to the standard of prime service, fast response in responding the customer service, and profit share to the members according to the scheduled period.

\section{c) Tabligh}

Tabligh is defined as transparency and can be openly accounted for. The managers have a tabligh characteristic in three things, namely, first, establishing a good and harmonious relationship between the managers and members through aspiration network periodically. Secondly, establishing a good relationship among managers through intensive coordination periodically. Third, establishing a good relationship between managers and the government through coaching and coordination.

In a good relationship between managers and members, transparent management is manifested by:

- $\quad$ Annual members meeting held within one year.

- First semester members' meeting held in July or August by inviting the head of group members to evaluate the work program and the revenue and expenditure budget for the first semester.

- Meeting of aspiration net members held in October and November.

- Second semester members' meeting held in December by inviting the head of the member group to evaluate the work program and the one year revenue and expenditure budget and the following year's discussion.

- Additional member meetings if it is required.

In the relationship between managers, transparent management is manifested in the form of:

- Monthly report of branch manager

- Quarterly report of branch manager

- Quarterly report of the management representative

- Weekly meeting (every thursday) among manager, supervisor, and management

Concerning the relationship with the government, transparent management is manifested in the form of quarterly reports to the Head of Department of Cooperative of UMKM East Java and Head of Department of Cooperative of Regency.

\section{d) Intelligent (Fathonah)}

Fathonah is defined as smart in managing the business towards a professional individual. The professionalism of the managers is performed through continuous learning by integrating science from the academicians and practitioners. The aim is for self-development so that it can give benefits to others.

The manifestation of the management of the fathonah is implemented by:

- Build standarddized operational management and procedures.

- All managers must understand management standards and procedures.

- $\quad$ All managers must be disciplined in applying 

field.

management standards and procedures according to their - Implementing accounting following the standard statements of financial accounting standards which are standardized in the form of computer application programs.

All offices, both centers, branches, sub-branches are equipped with computers that use the same application as the online network and electronic data capture.

Officer account officer who work out of the office, receive a financing or saving installment with a mobile printer connected to his or her office.

All managers are programmed to participate in training following their field taken from the 5\% allocation of the surplus.

The results of the study showed that spiritual leadership at BMT UGT Sidogiri was carried out to create a godly life in the workplace both individual and pious social. The current spiritual leadership does not separate from the teachings of Islam. The results of this study are different from the research conducted by Fry, which states that spirituality and [36]. Religion is seen as a theological system and ritual worship only, while spiritual is seen only as a quality of the soul. Accordingly, understanding spirituality in Islam is based on piety and faith in Allah SWT; it is challenging to integral part of spirituality [16,51].

Spiritual leadership is oriented so that employees are more effective at work because employees view their work as a tool to increase their spirituality by showing more significant effort in completing their work. This finding is in line with the research conducted by Zsolnai \& Illes [14]. Also, it aims to motivate and inspire employees through the creation of a vision and culture based on altruistic values so that employees have commitment and productivity $[12,32,36]$.

This study revealed that spiritual leadership at BMT UGT Sidogiri is implemented to make a pleasant atmosphere among the worker, either individual or social in the workplace. In this case, spiritual leadership aims at motivating the staffs to work effectively and efficient by showing their will in finishing the work due to its importance and how it will improve their spiritual life. Besides, spiritual leadership also intends to encourage and inspire the staffs through the making of vision and culture based on the altruistic value in case they have commitment and productivity. The conclusion supports the results of research conducted by [6].

\section{CONCLUSION}

This study revealed that spiritual leadership at BMT UGT Sidogiri was based on three main bases; they were Iman (faith or belief), Islam (sharia), and Ihsan (ethic). Iman teaches us to believe that Allah is the only God and his nature become an inspiration to apply in every activity, and we also have to believe that every deed we make should be done as pleasant as possible to be a part of adoration and useful for others. Moreover, the values of iman are reflected in their work including hard, discipline, always supervised, accompanied, and protected by Allah. Islamic bases is an underlying faith to Allah to strengthening business player religion are judged separately and not related to one another separate spirituality from religion. Religious rituals are an

spiritual which aims at harmonizing world and afterlife destination. It is reflected by the commitment of doing congregational prayers (salat al-jamaah). Someone who has an outstanding religious commitment will not forget religious ethics such as discipline, honest, virtuous, not arbitrary to others, and responsible for the job. Furthermore, ihsan bases lead the human being to have a good deed in pursuing happiness in the world and hereafter. It also teaches us to make a good relationship to God (Allah), human and themselves, other God's creatures and leads the human not to make destruction. Furthermore, related to the business field, the value of ihsan is reflected through the working culture. This culture is taken from the personality characters of Prophet such as shiddiq, amanah, tabligh, fathonah, which is implemented into working standards.

\section{REFERENCES}

1. Fry LW, Latham JR, Clinebell SK, Krahnke K. Spiritual leadership as a model for performance excellence: a study of Baldrige award recipients. J Manag Spiritual Relig. 2017 Jan 2;14(1):22-47.

2. Yang F, Qing T, Zhang L, Tang L. Feeling Energized: How and When Spiritual Leadership Enhances Employee Job Performance. Acad Manag Proc. 2017 Jan;2017(1):12424.

3. Klaus L, Fernando M. Enacting Spiritual Leadership in Business Through Ego-Transcendence. Leadersh Organ Dev J. 2016 Mar 7;37(1):71-92.

4. Aslan M, Korkut A. Spiritual Leadership in Primary Schools in Turkey. J Educ Soc Res [Internet]. 2015 May 1 [cited 2018 Sep 25]; Available from: http://www.mcser.org/journal/index.php/jesr/article/view 16566

5. Fairholm MR, Gronau TW. Spiritual leadership in the work of public administrators. J Manag Spiritual Relig. 2015 Oct 2;12(4):354-73.

6. Fry LW, Hannah ST, Noel M, Walumbwa FO. RETRACTED: Impact of spiritual leadership on unit performance. Leadersh Q. 2011 Apr;22(2):259-70.

7. Egel E, Fry LW. Spiritual Leadership as a Model for Islamic Leadership. Public Integr. 2017 Jan 2;19(1):7795.

8. Balog AM, Baker LT, Walker AG. Religiosity and spirituality in entrepreneurship: a review and research agenda. J Manag Spiritual Relig. 2014 Apr 3;11(2):15986.

9. Houston DJ, Cartwright KE. Spirituality and Public Service. Public Adm Rev. 2007 Jan;67(1):88-102

10. Anderson P. This place Hurt My Spirit. J Manag Spiritual Relig. 2018 Aug 8;15(4):305-24.

11. Geh E, Tan G. Spirituality at work in a changing world: managerial and research implications. J Manag Spiritual Relig. 2009 Dec;6(4):287-300.

12. Zsolnai L, Illes K. Spiritually inspired creativity in business. Int J Soc Econ. 2017 Feb 13;44(2):195-205.

13. Dehaghi MR, Goodarzi M, Arazi ZK. The Effect of Spiritual Values on Employees' Organizational Commitment and Its Models. Procedia - Soc Behav Sci. 2012 Oct;62:159-66.

14. Zsolnai L. Ethics Needs Spirituality. In: Nandram SS Borden ME, editors. Spirituality and Business [Internet]. Berlin, Heidelberg: Springer Berlin Heidelberg; 2010 [cited 2019 Mar 14]. p. 87-90. Available from: http://link.springer.com/10.1007/978-3-642-02661-4_7 
15. Moon T-W, Youn N, Hur W-M, Kim K-M. Does employees' spirituality enhance job performance? The mediating roles of intrinsic motivation and job crafting. Curr Psychol [Internet]. 2018 May 5 [cited 2019 Mar 14]; Available from: http://link.springer.com/10.1007/s12144-018-9864-0

16. Ahmad M, Khan S. A Model of Spirituality for Ageing Muslims. J Relig Health. 2016 Jun;55(3):830-43.

17. Ashar H, Lane-Maher M. Success and Spirituality in the New Business Paradigm. J Manag Inq. 2004 Sep;13(3):249-60.

18. Korac-Kakabadse N, Kouzmin A, Kakabadse A. Spirituality and leadership praxis. J Manag Psychol. 2002 May;17(3):165-82.

19. Stillman TF, Fincham FD, Vohs KD, Lambert NM, Phillips CA. The material and immaterial in conflict: Spirituality reduces conspicuous consumption. J Econ Psychol. 2012 Feb;33(1):1-7.

20. Boda Z, Zsolnai L. The failure of business ethics. Soc Bus Rev. 2016 Feb 8;11(1):93-104.

21. Velasquez M. Globalization and the Failure of Ethics. Bus Ethics Q. 2000 Jan;10(1):343.

22. Sarpong D, Sajdakova J, Adams K. The Mabey and Johnson bribery scandal: A case of executive hubris. Thunderbird Int Bus Rev [Internet]. 2018 May 22 [cited 2018 Oct 7]; Available from: http://doi.wiley.com/10.1002/tie.21989

23. Chen C-Y, Yang C-Y, Li C-I. Spiritual Leadership, Follower Mediators, and Organizational Outcomes: Evidence From Three Industries Across Two Major Chinese Societies1: SPIRITUAL LEADERSHIP IN CHINESE INDUSTRIES. J Appl Soc Psychol. 2012 Apr;42(4):890-938.

24. Phuong VN, Khanh HD. The Role of Leader's Spiritual Leadership on Organisation Outcomes. Asian Acad Manag J. 2018;23(2):45-68.

25. Pruzan P. Spiritual-based Leadership in Business. J Hum Values. 2008 Oct;14(2):101-14.

26. Wang M, Guo T, Ni Y, Shang S, Tang Z. The Effect of Spiritual Leadership on Employee Effectiveness: An Intrinsic Motivation Perspective. Front Psychol [Internet]. 2019 Jan 4 [cited 2019 Apr 8];9. Available from:

https://www.frontiersin.org/article/10.3389/fpsyg.2018.0 2627/full

27. Driscoll C, McIsaac EM, Wiebe E. The material nature of spirituality in the small business workplace: from transcendent ethical values to immanent ethical actions. J Manag Spiritual Relig. 2019 Mar 15;16(2):155-77.

28. Pohl F. Islamic Education and Civil Society: Reflections on the Pesantren Tradition in Contemporary Indonesia. Comp Educ Rev. 2006 Aug;50(3):389-409.

29. Siswanto S. The Exploration Of Pesantren - Based Entrepreneurship Development Strategy Through Teleology Approach. El Harakah Terakreditasi. 2018 Nov 29;20(2):191.

30. Zaki I, Mawardi I, Widiastuti T, Hendratmi A, Budiantoro RA. Business Model and Islamic Boarding School Business Development Strategy (Case Study Islamic Boarding School Sido Giri Pasuruan, East Java). KnE Soc Sci. 2019 Mar 31;3(13):602.

31. Directorate General of Islamic Education Ministry of Religion Republic of Indonesia. Develop Strategic Boarding Schools [Internet]. [cited 2019 Apr 14]. Available from: http://pendis.kemenag.go.id/index.php?a=detil\&id=9405

32. Karaoağ E. Spiritual leadership and organizational culture: A study of structural equation modeling. Kuram Ve Uygulamada Egitim Bilim. 2009 Jan 1;9:1391-405.
33. Fairholm GW. Capturing the heart of leadership: spirituality and community in the new American workplace. Westport, Conn: Praeger; 1997. 235 p.

34. Bensaid B, Machouche S, Grine F. A Qur'anic Framework for Spiritual Intelligence. Religions. 2014 Feb 26;5(1):179-98.

35. Tobroni. Memperbincangkan pemikiran pendidikan Islam: dari idealisme substantif hingga konsep aktual. Cetakan ke-1. Jakarta: Prenadamedia Group; 2018. 318 p.

36. Fry LW. Toward a theory of spiritual leadership. Leadersh Q. 2003 Dec;14(6):693-727.

37. Smith JA, Rayment JJ. The Global SMP Fitness Framework: A guide for leaders exploring the relevance of spirituality in the workplace. Manag Decis. 2007 Mar $13 ; 45(2): 217-34$

38. Usman A, Mahadi N, Quoquab F, Wei NR. The Development of Islamic Spiritual Leadership Concept. Adv Sci Lett. 2017 Apr 1;23(4):3003-5.

39. Hafidhuddin D, Tanjung H. Manajemen syariah dalam praktik. Jakarta: Gema Insani; 2003.

40. Creswell JW. Qualitative inquiry \& research design: choosing among five approaches. 2nd ed. Thousand Oaks: Sage Publications; 2007. 395 p.

41. Yin RK. Case study research: design and methods. Fifth edition. Los Angeles: SAGE; 2014. 282 p.

42. Miles MB, Huberman AM, Saldaña J. Qualitative data analysis: a methods sourcebook. Third edition. Thousand Oaks, Califorinia: SAGE Publications, Inc; 2014. 381 p.

43. Achour M. Islamic spirituality and entrepreneurship: A case study of women entrepreneurs in Malaysia. J Happiness Well-Being. 2015 Jan 1;3:41-56.

44. Rice G. Islamic Ethics and the Implications for Business. J Bus Ethics. 1999;18(4):345-58.

45. Beekun RI. Islamic business ethics. Herndon, Va: International Institute of Islamic Thought; 1997. $84 \mathrm{p}$ (Human development series).

46. Chapra MU. Islam and the economic challenge Leicester, UK: Herndon, VA: Islamic Foundation; International Institute of Islamic Thought; 1992. 428 p. (Islamic economics series).

47. Uddin SJ. Understanding the framework of business in Islam in an era of globalization: a review. Bus Ethics Eur Rev. 2003 Jan;12(1):23-32.

48. Ali AJ, Gibbs M. Foundation of business ethics in contemporary religious thought: the Ten Commandment perspective. Int J Soc Econ. 1998 Nov;25(10):1552-64.

49. Beekun RI, Badawi JA. Balancing Ethical Responsibility among Multiple Organizational Stakeholders: The Islamic Perspective. J Bus Ethics. 2005 Aug;60(2):13145.

50. Beekun RI. Character centered leadership: Muhammad (p) as an ethical role model for CEOs. El Garah W, editor. J Manag Dev. 2012 Oct 19;31(10):1003-20.

51. Bhatti OK, Alkahtani A, Hassan A, Sulaiman M. The Relationship between Islamic Piety (Taqwa) and Workplace Deviance with Organizational Justice as a Moderator. Int J Bus Manag. 2015 Mar 25;10(4):p136. 


\section{AUTHORS PROFILE}

Helmi Muhammad is a Ph.D student of Management Science, Faculty of Economics and Business, University of Brawijaya, Malang, specializing in financial management. He is also a lecturer at the Universitas Islam Raden Rahmat, Malang, Indonesia. His research is focusing on entrepreneurship, Islamic business ethics, Islamic micro finance, and so forth.

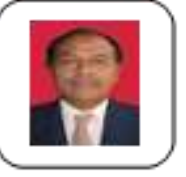

Moeljadiis a professor in financial management in Faculty of Economics and Business, University of Brawijaya, Malang. His doctoral education was attained from Universitas Airlangga Surabaya with the concentration of strategic management. Some research results that have been written are the Effect of Strategic Leadership and Role Conflict to Employee's Commitments with Work Stress as Mediation, Factors Affecting Firms Value of Indonesia Public Manufacturing Firms, Financial Flexibility Analysis of Export-Oriented Firm in East Java, ASEAN Islamic Stock Price, and Non-Islamic Stock Price, and so forth.

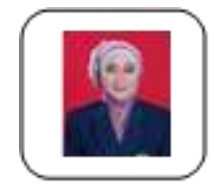

Nur Khusniyah Indrawati is a senior lecturer in Faculty of Economics and Business, University of Brawijaya, Malang, as well as the member of Indonesian Economic Scholars Association. She took the doctoral education in University of Brawijaya, Malang with the concentration of financial management. She is interested in research on small business finance, entrepreneurship, and business ethics.

Atim Djazuli is a senior lecturer in Faculty of Economics and Business, University of Brawijaya, Malang, as well as the member of Indonesian Economics Scholars Association. He received doctoral education in University of Brawijaya, Malang with the concentration of financial management. His studies are about investment management, financial and capital market management. 